\title{
Abnormalities in liver enzyme levels during Salmonella enteritidis enterocolitis
}

\author{
A. González-Quintela, J. Campos, R. Alende, A. López-Soto, S. Tomé, E. Otero and J. A. Torre \\ Department of Internal Medicine. Hospital Clínico Universitario. Santiago de Compostela. A Coruña. Spain
}

\begin{abstract}
Objective: to evaluate the prevalence, associated factors, and time-course changes of abnormal liver enzyme serum levels in adult patients with Salmonella enteritidis enterocolitis.

Methods: the clinical records of 104 patients (age range 1586 years, $46.2 \%$ males) admitted to hospital because of $S$. enteritidis enterocolitis were reviewed. The prevalence of abnormal liver enzyme levels was evaluated, as well as its possible relationship to data of systemic inflammatory response, severe sepsis, and bacteremia. In addition, time-course changes in serum levels of liver enzymes were studied in 16 cases with available follow-up after hospital discharge.

Results: in patients without a pre-existing cause for liver enzyme abnormalities $(n=84)$, the prevalence of serum AST elevation was 23.0\% (95\% CI 15.4-34.5\%), of serum ALT elevation was $17.9 \%$ (95\% CI $0.6-20.0 \%)$, and of GGT elevation was $19.0 \%$ (95\% CI 11.6-29.3\%). The prevalence of abnormality for any of these enzymes (AST, ALT, or GGT) was 35.7\% (95\% CI 25.7-46.8\%). The prevalence of altered serum alkaline phosphatase was lower. Alteration in liver enzyme serum levels was moderate in the majority of cases, and was found in association with the presence of fever. Serum enzyme levels decreased during the convalescence period after hospital discharge.

Conclusions: abnormalities in liver enzyme levels are frequent during severe enterocolitis due to $S$. enteritidis in adult patients. These abnormalities are moderate and self-limited.
\end{abstract}

Key words: Salmonella. Salmonella enteritidis. Enterocolitis. AST. ALT. GGT.

González-Quintela A, Campos J, Alende R, López-Soto A, Tomé S, Otero E, Torre JA. Abnormalities in liver enzyme levels during Salmonella enteritidis enterocolitis. Rev Esp Enferm Dig 2004; 96: 559-566.

Recibido: $16-10-03$

Aceptado: 12-01-04.

Correspondencia: Arturo González-Quintela. Servicio de Medicina Interna. Hospital Clínico Universitario. 15706 Santiago de Compostela. e-mail: mearturo@usc.es

\section{INTRODUCTION}

Salmonella spp. infections represent a common health problem worldwide, particularly in developing countries (1). Salmonella typhi infection induces a protracted febrile condition known as enteric or typhoid fever (1). Enteric fever is frequently associated with abnormalities in liver enzyme serum levels $(2,3)$. Furthermore, a small subset of patients with enteric fever develop a severe liver disease with jaundice, commonly known as Salmonella hepatitis (2-4). Among non-typhoidal salmonellae, Salmonella enteritidis (S. enteritidis) infection usually induces a self-limited diarrheal disease (acute enterocolitis) which may be associated with bacteremia and systemic manifestations, and is typically acquired from contaminated eggs in food (1). Reports of possible abnormalities in liver enzyme levels during enterocolitis due to $S$. enteritidis are scarce. In a series of patients with acute enterocolitis of varying causes, abnormally high transaminase levels were found in $10 \%$ of cases due to Salmonella spp. infection (5). In addition, a case of severe acute hepatitis in a patient with multi-organ system failure after $S$. enteritidis sepsis has been reported (6). The present study was aimed at evaluating the prevalence, associated factors, and time-course changes of abnormal liver enzyme levels in adult patients admitted to hospital because of acute enterocolitis due to $S$. enteritidis.

\section{PATIENTS AND METHODS}

\section{Study design}

This is an analytical cross-sectional (prevalence) study. In a subset of patients, a longitudinal follow-up was performed (retrospective cohort study). Data were obtained after a review of computerized clinical records.

\section{Setting}

Patients admitted to a short-term stay Unit of the Internal Medicine Department (Hospital Clínico Universitario, San- 
tiago de Compostela, Spain) with a diagnosis of enterocolitis due to $S$. enteritidis from January 1995 to July 2003 were included. Our center is a reference university hospital covering an area with approximately 500.000 inhabitants. Patients admitted to the short-stay unit have medical problems calling for an anticipated stay not longer than five days. Patients with enterocolitis are admitted to hospital in the presence of: a) evidence of severe sepsis; b) inability for oral rehydration; c) renal failure; or d) additional metabolic alterations. Routine therapy includes fasting, intravenous rehydration, and antimicrobial chemotherapy with either ciprofloxacin or ceftriaxone in the majority of cases.

\section{Study population}

A total of 107 patients were admitted to the Unit because of $S$. enteritidis enterocolitis during the study period. Of them, cases with at least one determination of liver enzyme levels during hospital admission $(n=104)$ were included in the study. All patients included fulfilled the following criteria: a) acute diarrheal illness; and b) microbiological or epidemiological evidence of $S$. enteritidis infection. Microbiological evidence included stool culture positivity (present in 87 of 101 studied cases, $86.1 \%$ ), or blood culture positivity (present in 24 out of 100 studied cases, 24.0\%). Epidemiological evidence included a diarrhea episode occurring during a microbiologically-proven $S$. enteritidis infection outbreak (four cases). Median age of included patients was 52 years (range, 15-86 years). Forty-eight patients (46.2\%) were males.

In 20 patients $(19.2 \%)$ there was a pre-existing liver disease or a known cause for it. This subgroup included 17 heavy drinkers, a patient with chronic hepatitis B, a patient with chronic hepatitis $\mathrm{C}$, and a patient with hereditary hemochromatosis. For an estimation of the prevalence of abnormal liver enzyme levels, only patients without such a history of liver disease $(n=84)$ were included.

In five patients $(4.8 \%)$ there was associated morbidity, which included a case of Crohn's disease, a case of nonHodgkin's lymphoma, an HIV-infected case, a case with Behçet's disease, and a case with celiac disease.

All patients were discharged from hospital without significant complications after a median stay of four days (range 1-10 days).

\section{Main outcome measures}

Serum aspartate-aminotransferase (sAST), alanineaminotransferase (sALT), gamma-glutamyl-transferase (sGGT), alkaline phosphatase (sAF) and bilirubin were assayed in a Hitachi analyzer (Boehringer-Mannheim, Mannheim, Germany). Serum samples were obtained during the first 72 hours of hospital admission in all cases. Upper reference levels for sAST, sALT, sGGT and sAF are $\leq 25$ $\mathrm{IU} / \mathrm{L}, \leq 29 \mathrm{IU} / \mathrm{L}, \leq 38 \mathrm{IU} / \mathrm{L}$, and $\leq 195 \mathrm{IU} / \mathrm{L}$, respectively. In patients younger than 18 years (five cases) the sAF determination was not considered when altered. An additional de- termination of liver enzyme levels performed after hospital discharge (median 24 days, range 13-60 days) was available for 16 patients with baseline alterations in liver tests. This determination was compared to baseline values in order to investigate time-course changes in liver enzyme levels after the acute period of disease.

The study investigated the possible relationship of abnormalities in liver enzyme levels with: a) detection of bacteremia; b) criteria of systemic inflammatory response (fever, tachycardia, altered white blood cell count); and c) criteria of severe sepsis (arterial hypotension, renal failure) (7). An axillary temperature higher than $38^{\circ} \mathrm{C}$ was considered to be fever. A heart rate higher than $90 \mathrm{bpm}$ was considered tachycardia. The presence of leukocytosis (more than 12,000 cells $/ \mathrm{mm}^{3}$ ), leukopenia (less than 4000 cells $/ \mathrm{mm}^{3}$ ) or left shift (more than $10 \%$ of band forms) were considered alterations in white blood cell counts. A systolic blood pressure lower than $90 \mathrm{mmHg}$ was considered arterial hypotension (7). A serum creatinine higher than $1.3 \mathrm{mg} / \mathrm{dL}$ was considered kidney failure.

\section{Statistical analysis}

The prevalence of abnormalities in liver enzyme levels were calculated with their corresponding $95 \%$ confidence intervals (CI). Numerical variables were represented as median and range values due to their non-normal distribution in the Kolmogorov test. The Chi-square test (with continuity correction, when needed) was used to compare proportions. The Mann-Whitney test was employed to compare numerical variables. Wilcoxon's test was employed for comparison of paired samples. Two-tailed p-values lower than 0.05 were considered statistically significant.

\section{Ethical considerations}

The study conformed to the Helsinki Declaration of 1975.

\section{RESULTS}

\section{Prevalence of abnormalities in liver enzyme levels}

In the sample studied, median (and range) liver enzymes were as follows: sAST $17 \mathrm{UI} / \mathrm{L}$ (7-426 UI/L), sALT $16 \mathrm{UI} / \mathrm{L}$ (6-617 UI/L), sGGT $18 \mathrm{UI} / \mathrm{L}$ (5-629 UI/L), and sAF 115 $\mathrm{UI} / \mathrm{L}(59-641 \mathrm{UI} / \mathrm{L})$.

In the group of patients with neither pre-existing liver disease nor a cause for it, the most frequent abnormalities were found for sAST, sALT and sGGT. The prevalence of elevation was as follows: sAST $23.0 \%$ (95\% CI 15.4$34.5 \%$ ), sALT $17.9 \%$ (95\% CI 10.6-20.0\%), and sGGT $19.0 \%$ (95\% CI 11.6-29.3\%). The prevalence of abnormality in any of these parameters (sAST, sALT, or sGGT) was $35.7 \%$ (95\% CI 25.7-46.8\%). The individual levels of sAST, SALT, and sGGT in patients without pre-existing liver dis- 
ease are represented in figure 1 . In two patients $(2.3 \%, 95 \%$ CI $0.4-9.1 \%$ ) serum transaminase elevation reached the range of acute hepatitis (sAST or sALT higher than 10-fold the highest normal level). Abnormalities in sAF were less frequent. In patients without pre-existing liver disease the prevalence of abnormal sAF was $6.1 \%$ (95\% CI 2.2-14.2\%), with a median of $111 \mathrm{IU} / \mathrm{L}$ (range 59-141 IU/L). In all but two cases sAF increase was associated with sGGT increase. Clinically detectable bilirubin elevations were observed in no cases (median $0.7 \mathrm{mg} / \mathrm{dL}$, range $0.2-2.6 \mathrm{mg} / \mathrm{dL}$ ).

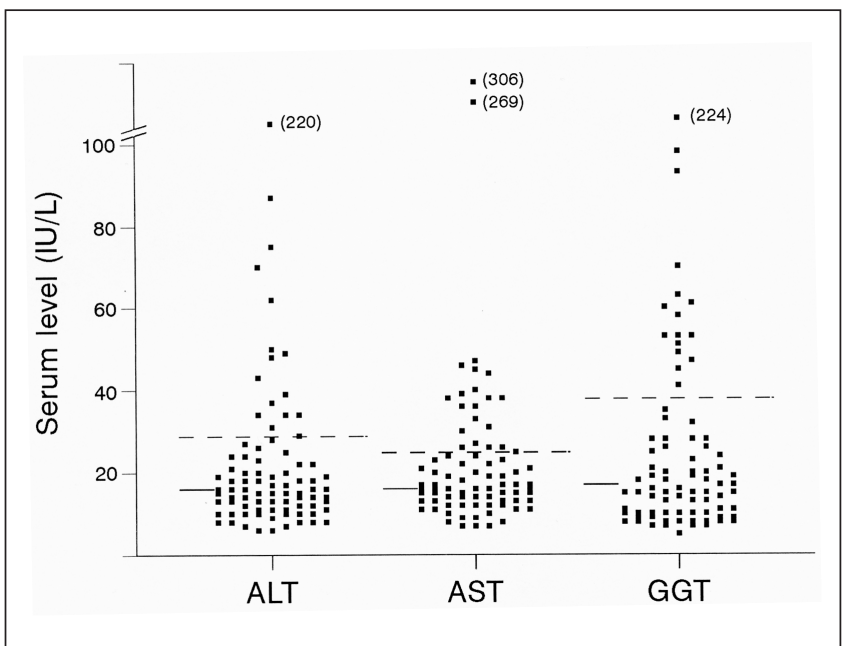

Fig. 1.- Levels of SAST, SALT and SGGT in patients with neither pre-existing liver disease nor a known cause for it. Horizontal dashed lines represent the upper normal reference value. Horizontal solid lines represent median values.

Niveles séricos de AST, ALT y GGT en los pacientes sin causa previa de hepatopatía. Las líneas discontinuas horizontales representan el nivel superior de la normalidad. Las líneas continuas horizontales representan la mediana.

\section{Association of abnormalities in liver enzyme levels with potential factors}

Table I provides a comparison of demographic and clinical variables between patients with and without abnormalities in liver enzyme levels (sAST, sALT or sGGT) within the group of cases without pre-existing liver disease. $\mathrm{Pa}-$ tients with abnormalities in liver enzyme levels presented a higher prevalence of fever than patients without abnormalities. Bacteremia was more frequent in patients with abnormalities in liver enzyme levels but the difference was not statistical significant. Serum creatinine levels were slightly higher in patients with abnormalities in liver enzyme levels that in patients without them (median $1.0 \mathrm{mg} / \mathrm{dL}$ and range 0.7-3.5 $\mathrm{mg} / \mathrm{dL}$ vs median $0.9 \mathrm{mg} / \mathrm{dL}$ and range 0.6-4.3 $\mathrm{mg} / \mathrm{dL}$, respectively, $\mathrm{p}=0.04$ ), but the prevalence of renal failure was not significantly different between both groups (Table I). No differences were observed in the prevalence of arterial hypotension, tachycardia, altered white blood cell counts, or antibiotic administration between patients with abnormalities in liver enzyme levels and patients without them (Table I).
Table I. Demographic and clinical characteristics of patients with and without abnormal liver enzyme serum levels (sAST, sALT or SGGT) ${ }^{\mathrm{a}}$

\begin{tabular}{lccc}
\hline Factors & $\begin{array}{c}\text { Patients with } \\
\text { abnormal levels } \\
(n=30)\end{array}$ & $\begin{array}{c}\text { Patients without } \\
\text { abnormal levels } \\
(n=54)\end{array}$ & $p$-value \\
\hline Age (years) & $53(15-75)$ & $52(15-86)$ & 0.48 \\
Gender (male) & $15(50.0 \%)$ & $19(35.2 \%)$ & 0.18 \\
Fever & $21(70.0 \%)$ & $25(46.3 \%)$ & 0.03 \\
Tachycardia $_{\text {White blood cell abnormality }}{ }^{b}$ & $29(96.7 \%)$ & $2(3.7 \%)$ & 0.93 \\
Arterial hypotension $_{\text {Renal failure }}$ & $4(13.3 \%)$ & $47(87.0 \%)$ & 0.15 \\
Positive blood culture $^{c}$ & $8(26.7 \%)$ & $10(18.4 \%)$ & 0.61 \\
Antibiotic administration $^{d}$ & $8(27.6 \%)$ & $9(17.6 \%)$ & 0.38 \\
\hline
\end{tabular}

${ }^{\mathrm{a}}$ Twenty patients with pre-existing liver disease or a cause for it were excluded from analyses.

'Leukocytosis, leukopenia or left shift.

'Data available for 80 out of 84 patients.

${ }^{\mathrm{a}}$ Ciprofloxacin in 74 cases, ceftriaxone in two cases.

Figures are median and range (within parentheses) values or absolute frequencies and percentages (within parentheses).

\section{Time-course changes of liver enzyme serum levels during the convalescence period}

Figure 2 represents the outcome of SAST, sALT and sGGT levels during the convalescence period after hospital

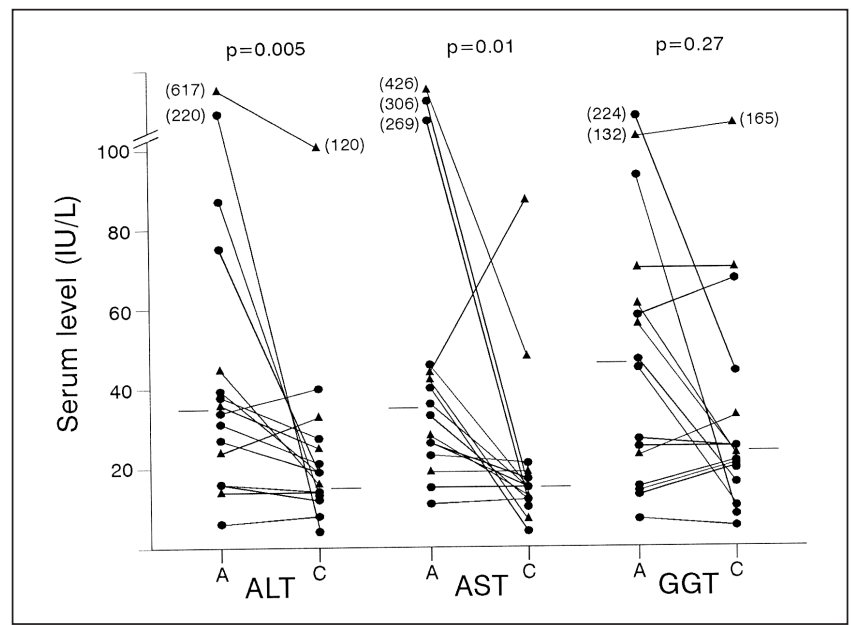

Fig. 2.- Time-course changes of SAST, SALT and SGGT levels in patients with a second determination after hospital discharge. All cases presented abnormality in at least one parameter during the in-hospital acute phase. Circles represent patients with neither pre-existing liver disease nor a known cause for it. Triangles represent patients with pre-existing liver disease. Horizontal dashed lines represent the upper normal reference value. Horizontal solid lines represent median values. A: acute phase (during hospital admission); C: convalescence phase (after hospital discharge).

Evolución de los niveles séricos de AST, ALT y GGT en los pacientes en los que se dispuso de segunda determinación tras el alta hospitalaria. Todos los pacientes presentaban alteración en al menos uno de los parámetros durante la fase aguda. Los círculos representan pacientes sin causa previa de hepatopatía, y los triángulos representan pacientes con causa previa de hepatopatía. Las líneas discontinuas horizontales representan el nivel superior de la normalidad. Las líneas continuas horizontales representan la mediana. A: fase aguda (durante el ingreso hospitalario); C: fase de convalencencia (tras el alta hospitalaria). 
discharge in 16 patients with some alteration in these enzymes during the acute phase. There was a trend towards decrease of all three liver enzymes (statistically significant for sAST and SALT). This trend was observed in patients with and without pre-existing liver disease, but was particularly significant in patients without it $(p=0.007$ and $p=$ 0.01 for sASL and SALT, respectively), and in patients with the highest enzyme levels during the acute phase (Fig. 2). In patients without pre-existing liver disease, sAST levels went back to normal in all nine patients with baseline elevation, and sALT levels went back to normal in six out of seven patients with baseline elevation.

\section{DISCUSSION}

The present study shows that a sizeable proportion of patients with enterocolitis due to $S$. enteritidis present abnormalities in liver enzyme levels, particularly sAST, sALT and sGGT. These abnormalities are mild in the majority of cases, and self-limited.

Previous references of liver abnormalities during infectious enterocolitis are scarce. In a retrospective study of 727 cases of enterocolitis, Tositti et al. found that rotavirus was the most common cause of sALT increase, and suggested that rotavirus infection should be suspected in adult patients with acute diarrhea and serum transaminase elevation (5). These same authors, however, found that SALT was increased in 13 out of 125 cases (10\%) of enterocolitis due to Salmonella spp. in patients without previous liver disease (5), a figure similar to that found in the present study. Abnormalities in liver enzyme levels during $S$. enteritidis enterocolitis have biological plausibility. S. enteritidis infection in these cases is apparently limited to the gastrointestinal tract, but is frequently accompanied by manifestations of systemic inflammatory response. Abnormalities in liver enzyme levels, together with additional systemic manifestations of $S$. enteritidis infection may be caused by a leaking of either bacteria or their products to the circulation (6), with subsequent immune activation and production of cytokines with potential liver toxicity. Thus, abnormalities in liver enzyme levels during $S$. enteritidis enterocolitis may be included in the liver dysfunction syndrome during sepsis $(8,9)$. No data are available to affirm whether or not these abnormalities are more frequent in S. enteritidis infections than in other infections. In the studied population, however, abnormalities in liver enzyme levels were associated with fever but not with additional evidence of systemic inflammatory response (tachycardia or white blood cell count alterations), data of severe sepsis (arterial hypotension, renal failure) or detectable bacteremia.

The methodological limitations of this kind of studies should be considered. As far as selection of cases is concerned, it should be taken into account that the studied population consisted of in-hospital patients. All of them had an indication for admission, thus meaning that enterocolitis may be classified as severe in all cases (10). For this same reason, the vast majority of patients received antimicrobial chemotherapy. The refer- ence population to whom results could be extrapolated should therefore be patients with $S$. enteritidis enterocolitis of similar severity. In addition, prevalence studies are not optimal to establish causal relationships ( $S$. enteritidis infection as a cause of abnormalities in liver enzyme levels in this case) due to temporal ambiguity. Although cases with pre-existing liver disease (or a cause for it) were excluded in prevalence studies, it is possible that some additional patients had abnormalities in liver enzyme levels prior to their enterocolitis episode. Specifically, there were no available data to evaluate overweight as a cause for such abnormalities. The most frequent cause of liver disease in the sample studied was alcohol consumption, which in addition may modify the severity of $S$. enteritidis infections $(11,12)$

Even with those limitations, the role of $S$. enteritidis infection in the development of liver enzyme abnormalities is supported by consistency with previous studies (5), analogy with liver abnormalities during different Salmonella spp. infections $(2,3)$, and the already mentioned biological plausibility. The longitudinal study (retrospective cohort study), although performed in a short number of cases, demonstrated a significant decrease of liver enzyme levels during convalescence, further suggesting that $S$. enteritidis infection was the cause of abnormalities in liver enzyme levels. Such abnormalities are mild and transient, but are also frequent and should be taken into account in patients with severe $S$. enteritidis enterocolitis.

\section{REFERENCES}

1. Lesser CF, Miller SI. Salmonellosis. En: Braunwald E, Fauci AS, Kasper DL, Hauser SL, Longo DL, Jameson JL, eds. Harrison's Principles of Internal Medicine. 15th Ed. New York: McGraw-Hill, 2001. p. 970-5.

2. El-Newihi H, Alamy ME, Reynolds TB. Salmonella hepatitis: analysis of 27 cases and comparison with acute viral hepatitis. Hepatology 1996; 24: 516-9.

3. Pramoolsinsap C, Viranuvatti V. Salmonella hepatitis. J Gastroenterol Hepatol 1998; 13: 745-50.

4. Rodriguez Cuartero A, Rodriguez Fassio MA. Hepatitis aguda tífica. Rev Esp Enferm Dig 1993; 84: 133-4.

5. Tositti G, Fabris P, Romano L, de Lalla F. Liver injury during gastroenteritis in adults: a retrospective study in 727 cases. Am J Gastroenterol 2002; 97; 487-8.

6. Retornaz F, Fournier PE, Seux V, Jacomo V, Soubeyrand J. A case of Salmonella enteritidis septicemia complicated by disseminated intravascular coagulation, severe hepatitis, rhabdomyolisis and acute renal failure. Eur J Clin Microbiol Infect Dis 1999; 18: 830-41.

7. ACCP/SCCM (American College of Chest Physicians/Society of Critical Care Medicine) Consensus Conference Committee. Definitions for sepsis and organ failure and guidelines for the use of innovative therapies in sepsis. Crit Care Med 1992; 20: 864-74.

8. Sikuler E, Guetta V, Keynan A, Neumann L, Schalaeffer F. Abnormalities in bilirubin and liver enzyme levels in adult patients with bacteremia. A prospective study. Arch Intern Med 1989; 149: 2246-8.

9. Wang P, Chaudry IH. Mechanism of hepatocellular dysfunction during hyperdynamic sepsis. Am J Physiol 1996; 270: R927-38.

10. Goodman LJ, Segreti J. Diarrheal disease and gastroenteritis. Infect Dis Emerg Med 1992; 2: 591-605.

11. Bassa A, Parras F, Reina J, Villar E, Gil J, Alomar P. Non-typhi Salmonella bacteraemia. Infection 1989; 17: 290-3.

12. Galofre J, Moreno A, Mensa J, Miro J, Gatell J, Almela M, et al Analysis of factors influencing the outcome and development of septic metastasis or relapse in Salmonella bacteremia. Clin Infect Dis 1994; 18: 873-8. 


\title{
Alteraciones en los niveles séricos de enzimas hepáticos durante la enterocolitis por Salmonella enteritidis
}

\author{
A. González-Quintela, J. Campos, R. Alende, A. López-Soto, S. Tomé, E. Otero y J. A. Torre \\ Servicio de Medicina Interna. Hospital Clínico Universitario. Santiago de Compostela. A Coruña
}

\section{RESUMEN}

Objetivo: evaluar la prevalencia, los factores asociados y la evolución de las anormalidades en los niveles séricos de enzimas hepáticos en pacientes adultos con enterocolitis por $S$. enteritidis.

Métodos: se revisaron los historiales de 104 pacientes (de edades comprendidas entre 15 y 86 años, 46,2\% varones), ingresados en un hospital por enterocolitis aguda por $S$. enteritidis. Se evaluó la prevalencia de alteración en los niveles séricos de enzimas hepáticos y su asociación con datos de respuesta inflamatoria sistémica, de sepsis grave y con la presencia de bacteriemia detectable. Asimismo, se estudió la evolución de los parámetros de función hepática en 16 casos en los que se dispuso de seguimiento pasada la fase aguda tras el alta hospitalaria.

Resultados: en los pacientes sin causa previa de hepatopatía ( $n=84$ ), la prevalencia de elevación de la AST fue 23,0\% (IC 95\% 15,4-34,5\%), de ALT 17,9\% (IC 95\% 10,6-20,0\%), y de GGT 19,0\% (IC 95\% 11,6-29,3\%). La prevalencia de alteración en alguno de esos parámetros (AST, ALT, o GGT) fue 35,7\% (IC 95\% 25,7-46,8\%). La prevalencia de alteración en fosfatasa alcalina fue menor. La alteración fue leve en la gran mayoría de los casos. La alteración en los enzimas hepáticos se asoció con la presencia de fiebre. Durante la convalecencia tras el alta hospitalaria se observó una tendencia a la disminución en los niveles de los parámetros estudiados.

Conclusiones: las alteraciones en los enzimas hepáticos (en general leves, y autolimitadas) son frecuentes en los pacientes con enterocolitis grave por $S$. enteritidis.

Palabras clave: Salmonella. Salmonella enteritidis. Enterocolitis. AST. ALT. GGT.

\section{INTRODUCCIÓN}

Las infecciones por Salmonella spp. siguen siendo un grave problema en todo el mundo, particularmente en países en vías de desarrollo (1). Las infecciones por Salmonella typhi producen una enfermedad febril prolongada, conocida como fiebre tifoidea o fiebre entérica (1). La fiebre tifoidea se asocia frecuentemente con alteraciones en las pruebas hepáticas de laboratorio $(2,3)$. Incluso, una pequeña proporción de pacientes con fiebre tifoidea desarrolla una enfermedad hepática grave, con ictericia franca, conocida como hepatitis por Salmonella o hepatitis tífica (2-4). Dentro de las infecciones por salmonellas no-typhi, Salmonella enteritidis (S. enteritidis) suele producir una enfermedad diarreica autolimitada (enterocolitis aguda), típicamente asociada al consumo de alimentos preparados con huevos contaminados, que se puede acompañar de bacteriemia y síntomas sistémicos (1). La información publicada acerca de las posibles alteraciones en las pruebas hepáticas de laboratorio durante la enterocolitis por $S$. enteritidis es muy limitada. En una serie de pacientes con enterocolitis aguda de una variedad de causas, se observó elevación de transaminasas (ALT) en un 10\% de los casos debidos a infección por Salmonella spp. (5). También se ha descrito un caso aislado de hepatitis grave en un paciente con fallo multiorgánico debido a sepsis por $S$. enteritidis (6). El objetivo del presente estudio fue evaluar la prevalencia, los factores asociados y la evolución de las anormalidades en los niveles séricos de enzimas hepáticos en pacientes adultos ingresados en el hospital por enterocolitis debida a infección por S. enteritidis.

\section{PACIENTES Y MÉTODOS}

\section{Tipo de estudio}

Se trata de un estudio transversal (de prevalencia), analítico. En una parte de los pacientes se ha realizado seguimiento longitudinal (estudio de cohorte retrospectiva). Los datos se han obtenido de la revisión de los historiales clínicos informatizados de los pacientes.

\section{Ámbito del estudio}

Se incluyeron los pacientes diagnosticados de enterocolitis por S. enteritidis en la Unidad Médica de Alta Precoz del Servicio de Medicina Interna del Hospital Clínico Universitario de Santiago de Compostela entre enero de 1995 y julio de 2003. El hospital es un centro de referencia que cubre un área sanitaria de aproximadamente 500.000 habitantes. La Unidad de Alta Precoz ingresa pacientes con problemas médicos que previsiblemente puedan ser dados de alta en un periodo menor a 5 días. Las enterocolitis agudas se ingresan en el hospital cuando revisten gravedad por estado séptico, por imposibilidad para la rehidratación oral, por insuficiencia renal debida a deshidratación o por otras alteraciones metabólicas. El tratamiento habitual incluye, en todos los casos, dieta y rehidratación intravenosa, y en la mayoría de los casos, administración de antibióticos (ciprofloxacino o ceftriaxona) por vía parenteral. 


\section{Sujetos a estudio}

Durante el periodo de estudio fueron ingresados 107 pacientes con el diagnóstico de enterocolitis por $S$. enteritidis. Se incluyeron en el estudio los 104 pacientes en los que se dispuso de determinación básica de transaminasas (ver más adelante). Todos los pacientes incluidos presentaban: a) una enfermedad diarreica aguda; y b) evidencia microbiológica o epidemiológica de infección por S. enteritidis. En la evidencia microbiológica se incluyó la positividad de coprocultivo (presente en 87 de 101 casos estudiados, 86,1\%) o la positividad de hemocultivo (presente en 24 de 100 casos estudiados, 24,0\%). En la evidencia epidemiológica se incluyó la diarrea aguda en el seno de una microepidemia en la que en al menos en algún caso índice se hubiese aislado $S$. enteritidis (cuatro casos). La edad mediana de los pacientes incluidos era 52 años (rango, 15-86 años). Un total de 48 pacientes eran varones $(46,2 \%)$.

En 20 pacientes $(19,2 \%)$ existía el antecedente conocido de hepatopatía o causa de ella. Este subgrupo incluía 17 casos con consumo excesivo de alcohol, un caso con hepatitis crónica por virus hepatitis $\mathrm{B}$, un caso con hepatitis crónica por virus hepatitis $\mathrm{C}$, y un caso de hemocromatosis hereditaria. Para la estimación de la prevalencia de alteración en las pruebas hepáticas y los factores asociados a las mismas se incluyeron sólo los pacientes sin causa previa de hepatopatía $(\mathrm{n}=84)$.

En cinco pacientes $(4,8 \%)$ existía otra comorbilidad asociada, que incluía un caso con enfermedad de Crohn, un caso con linfoma no-Hodgkin, un caso con infección por virus de la inmunodeficiencia humana, un caso con angioBehçet, y un caso con enfermedad celiaca.

Todos los pacientes fueron dados de alta hospitalaria sin complicación significativa tras una estancia mediana de cuatro días (rango, 1-10 días).

\section{Determinaciones principales}

La aspartato-aminotransferasa (AST), alanina-aminotransferasa (ALT), gamma-glutamil-transpeptidasa (GGT), fosfatasa alcalina (FA) y bilirrubina se determinaron en suero en un autoanalizador Hitachi (Boehringer-Mannheim, Mannheim, Alemania). Dicha muestra de suero fue tomada dentro de las primeras 72 horas de ingreso en todos los casos. Los niveles séricos normales de referencia para la AST, ALT, GGT y FA con el método descrito son $\leq 25 \mathrm{UI} / \mathrm{L}, \leq 29 \mathrm{UI} / \mathrm{L}, \leq 38$ $\mathrm{UI} / \mathrm{L}, \mathrm{y} \leq 195 \mathrm{UI} / \mathrm{L}$, respectivamente. En los pacientes con edad inferior a 18 años (cinco casos) no se tuvo en cuenta la determinación de FA en caso de estar alterada. Además, en 16 de los pacientes que presentaban alguna alteración en los enzimas hepáticos en la determinación tomada durante el ingreso, existía en el historial clínico una segunda determinación tomada en la convalecencia tras el alta hospitalaria, a una mediana de 24 días tras el alta (rango, 13-60 días). Esta determinación se comparó con la basal para conocer la evolución de los parámetros estudiados pasada la fase aguda.

Se estudió la posible asociación entre la presencia de alteraciones en los enzimas hepáticos y: a) presencia de bacte- riemia; b) datos de síndrome de respuesta inflamatoria sistémica (fiebre, taquicardia, alteraciones en los recuentos leucocitarios en sangre periférica); y c) datos de sepsis grave (hipotensión arterial, insuficiencia renal) (7). Se consideró fiebre la temperatura axilar mayor de $38{ }^{\circ} \mathrm{C}$. Se consideró taquicardia la frecuencia cardiaca mayor de 90 latidos por minuto. Se consideró alteración leucocitaria la presencia de leucocitosis (más de 12.000 células $/ \mathrm{mm}^{3}$ ), leucopenia (menos de 4000 células $/ \mathrm{mm}^{3}$ ) o desviación izquierda (más de $10 \%$ de cayados). Se consideró hipotensión la tensión arterial sistólica menor de $90 \mathrm{mmHg}$ (7). Se consideró insuficiencia renal la presencia de una creatinina sérica mayor de $1,3 \mathrm{mg} / \mathrm{dL}$.

\section{Análisis estadístico}

Se evaluó la prevalencia de alteraciones en los enzimas hepáticos, con su intervalo de confianza al 95\%. Las variables continuas se expresaron como mediana y rango dada la distribución no-normal de muchas de ellas en el test de Kolmogorov. Para la comparación de proporciones se utilizó el test Chi cuadrado (con la corrección de continuidad cuando fue preciso). Para la comparación de variables continuas (datos no pareados) se empleó el test de Mann-Whitney. Para la comparación de variables continuas (datos pareados -evolución temporal de los enzimas hepáticos-) se empleó el test de Wilcoxon. Se consideraron estadísticamente significativos los valores de 'p' (con dos colas) menores de 0,05.

\section{Consideraciones éticas}

El estudio se realizó conforme a los principios de la Declaración de Helsinki de 1975.

\section{RESULTADOS}

\section{Prevalencia de alteraciones en los enzimas hepáticos}

En el conjunto de la muestra estudiada, la mediana y rango de AST, ALT, GGT, FA fueron 17 UI/L (7-426 UI/L), 16 UI/L (6-617 UI/L), $18 \mathrm{UI} / \mathrm{L}$ (5-629 UI/L) y $115 \mathrm{UI} / \mathrm{L}$ (59$641 \mathrm{UI} / \mathrm{L})$, respectivamente.

En el subgrupo de pacientes sin causa previa de hepatopatía, las alteraciones más frecuentes se encontraron en la AST, ALT y GGT. La prevalencia de alteración (elevación) de la AST fue 23,0\% (IC 95\% 15,4-34,5\%), de ALT 17,9\% (IC $95 \% 10,6-20,0 \%$ ), y de GGT $19,0 \%$ (IC 95\% 11,6-29,3\%). La prevalencia de alteración en alguno de estos parámetros (AST, ALT, o GGT) fue 35,7\% (IC 95\% 25,7-46,8\%). Los valores de AST, ALT, y GGT en los pacientes sin causa previa de hepatopatía se representan en la figura 1 . En dos pacientes (2,3\%, IC 95\% 0,4-9,1\%) la elevación de transaminasas alcanzó rango de hepatitis aguda (AST o ALT mayor de 10 veces el valor superior de la normalidad). Las alteraciones en la FA fueron menos frecuentes. En el subgrupo de pacientes sin causa previa de hepatopatía, la prevalencia de alteración en la FA 
fue $6,1 \%$ (IC 95\% 2,2-14,2\%), con una mediana de $111 \mathrm{UI} / \mathrm{L}$ y rango 59-141 UI/L. En todos los casos, salvo en dos, el aumento de FA se asoció a aumento de GGT. En ningún caso se observó elevación de bilirrubina clínicamente detectable (mediana 0,7 mg/dL, rango 0,2-2,6 mg/dL).

\section{Asociación de las alteraciones en los enzimas hepáticos con otros factores}

En la tabla I se representa una comparación de variables demográficas y clínicas entre los pacientes con y sin alteración en los enzimas hepáticos (AST, ALT o GGT), dentro del subgrupo de pacientes sin causa previa de hepatopatía. Los pacientes con alteración en los enzimas hepáticos presentaron una mayor prevalencia de fiebre que los pacientes sin alteraciones. La bacteriemia se detectó con mayor frecuencia en los pacientes con alteración en los enzimas hepáticos que en los pacientes sin ella, pero la diferencia no alcanzó la significación estadística. Las cifras de creatinina fueron ligeramente mayores en los pacientes con alteraciones en los enzimas hepáticos que en los pacientes sin ellas (mediana 1,0 mg/dL y rango $0,7-3,5 \mathrm{mg} / \mathrm{dL}$ versus mediana $0,9 \mathrm{mg} / \mathrm{dL}$ y rango $0,6-$ $4,3 \mathrm{mg} / \mathrm{dL}$, respectivamente, $\mathrm{p}=0,04$ ), pero la prevalencia de insuficiencia renal no fue significativamente distinta en ambos grupos (Tabla I). No se observaron diferencias en la prevalencia de hipotensión arterial, taquicardia, alteraciones en los recuentos leucocitarios o administración de antibiótico entre los pacientes con y sin alteración en los enzimas hepáticos mencionados (Tabla I).

\section{Evolución de los enzimas hepáticos durante la convalecencia}

En la figura 2 se representan los valores de AST, ALT y GGT en los 16 pacientes con alguna alteración en los enzi-

Tabla I. Comparación de variables demográficas y clínicas entre los pacientes con y sin alteración en los enzimas hepáticos (AST, ALT o GGT séricas)a

\begin{tabular}{lccc}
\hline Factores & $\begin{array}{c}\text { Con alteración } \\
(n=30)\end{array}$ & $\begin{array}{c}\text { Sin alteración } \\
(n=54)\end{array}$ & Valor de $p$ \\
\hline Edad (años) & $53(15-75)$ & $52(15-86)$ & 0.48 \\
Sexo (masculino) & $15(50.0 \%)$ & $19(35,2 \%)$ & 0,18 \\
& & & \\
Fiebre & $21(70,0 \%)$ & $25(46,3 \%)$ & 0,03 \\
Taquicardia & $2(6,7 \%)$ & $2(3,7 \%)$ & 0,93 \\
Alteración leucocitariab $^{b}$ & $29(96,7 \%)$ & $47(87,0 \%)$ & 0,15 \\
Hipotensión arterial $^{\text {Insuficiencia renal }}$ & $4(13,3 \%)$ & $11(20,4 \%)$ & 0,61 \\
Hemocultivo positivo $^{c}$ & $8(26,7 \%)$ & $10(18,5 \%)$ & 0,38 \\
& $8(27,6 \%)$ & $9(17,6 \%)$ & 0,29 \\
Administración de antibiótico $^{d}$ & $28(93,3 \%)$ & $48(88,9 \%)$ & 0,50 \\
\hline
\end{tabular}

aDe los 104 pacientes del estudio se excluyeron, para el presente análisis, los 20 que presentaban hepatopatía previa conocida o causa de ella.

-Presencia de leucocitosis, leucopenia o desviación izquierda.

'Dato disponible en 80 de los 84 pacientes.

${ }^{\mathrm{d}}$ Ciprofloxacino en 74 casos, ceftriaxona en dos casos.

Los datos se representan como mediana y rango (entre paréntesis) o como frecuencia absoluta y porcentaje (entre paréntesis). mas hepáticos en los que se dispuso de una segunda determinación de estos parámetros durante la convalecencia tras el alta hospitalaria. Destaca la tendencia a la disminución de los valores en todos estos parámetros, disminución que fue estadísticamente significativa en el caso de la AST y la ALT. Esta tendencia a la disminución (normalización) se observó tanto en los pacientes con causa previa de hepatopatía como en los pacientes sin ella. La disminución de AST y ALT fue especialmente significativa en los casos sin causa previa de hepatopatía ( $\mathrm{p}=0,007$ y $\mathrm{p}=0,01$, respectivamente), y sobre todo en los que presentaban mayores niveles de esas enzimas durante la fase aguda (Fig. 2). Entre los pacientes sin causa previa de hepatopatía, la cifra de AST se normalizó en los nueve pacientes que la presentaban elevada en la fase aguda, y la cifra de ALT se normalizó en seis de los siete pacientes que la presentaban elevada en la fase aguda.

\section{DISCUSIÓN}

El presente estudio demuestra que una alta proporción de pacientes con enterocolitis aguda por $S$. enteritidis presenta alteración en los niveles séricos de enzimas hepáticos de uso habitual, sobre todo AST, ALT y GGT. Esta alteración es leve en la mayoría de los casos, y transitoria.

Existen pocas referencias en la literatura sobre alteraciones hepáticas durante episodios de enterocolitis aguda infecciosa. En un estudio retrospectivo de 727 casos de enterocolitis, Tositti y cols. encontraron que los rotavirus eran la causa de elevación de ALT sérica de forma más frecuente y más marcada, por lo que sugirieron que la infección por rotavirus debe sospecharse en pacientes adultos con diarrea aguda y elevación de transaminasas (5). Dichos autores, sin embargo, encontraron elevación de ALT en 13 de 125 casos (10\%) de enterocolitis por Salmonella spp. en pacientes sin hepatopatía previa conocida (5), cifra similar a la encontrada en el presente estudio. Resulta plausible que la enterocolitis por $S$. enteritidis se acompañe de alteraciones en los enzimas hepáticos ya que, si bien se trata de una infección aparentemente limitada al tubo digestivo, se acompaña frecuentemente de manifestaciones que reflejan respuesta inflamatoria sistémica. La alteración de los enzimas hepáticos, como otras manifestaciones sistémicas de la infección por $S$. enteritidis, podría estar causada por el paso al torrente circulatorio de gérmenes o sus productos (6) y la consiguiente activación inmunitaria y producción de citoquinas o otras sustancias con capacidad hepatotóxica. De esta forma, las alteraciones hepáticas inducidas por la infección por $S$. enteritidis serían similares a las de un "hígado de sepsis" $(8,9)$ de cualquier otra etiología. No disponemos de datos para afirmar si la frecuencia o gravedad de las alteraciones hepáticas durante la enterocolitis por $S$. enteritidis son diferentes de las inducidas por otros agentes infecciosos. En la población estudiada, sin embargo, las alteraciones en los enzimas hepáticos (AST, ALT o GGT) se asociaron con la presencia de fiebre, pero no de forma significativa con otros datos clínicos de síndrome de respuesta inflamatoria sistémica (taquicardia, alteraciones en los recuentos leucocitarios), con datos de 
sepsis grave (hipotensión arterial, insuficiencia renal), ni con la presencia de bacteriemia detectable.

En la interpretación de los resultados, es preciso tener en cuenta las limitaciones de este tipo de estudios. En cuanto a posibles sesgos por la forma de selección de los pacientes, hay que tener en cuenta que el estudio fue realizado en pacientes ingresados en el hospital. Todos ellos presentaban algún dato para requerir dicho ingreso, de forma que en todos los casos la enterocolitis podría ser clasificable como grave (10). Esta es la razón de que una elevada proporción de los pacientes fueran tratados con antibióticos. La población de referencia a la que podrían ser extrapolables los resultados serían, por tanto, los pacientes con enterocolitis por $S$. enteritidis de similar gravedad. Por otra parte, los estudios de prevalencia no son ideales para establecer causalidad (en este caso en la asociación entre enterocolitis por $S$. enteritidis y alteraciones en los enzimas hepáticos) por el posible sesgo de ambigüedad temporal. Aunque para los análisis de prevalencia se excluyeron los pacientes con hepatopatía conocida o causa de ella, no se puede descartar que algunos pacientes presentasen la alteración en los enzi- mas hepáticos previamente al episodio de enterocolitis. El sobrepeso como causa de tal alteración no se pudo valorar. La causa de hepatopatía previa más frecuentemente encontrada fue el consumo excesivo de alcohol, que además puede modificar la gravedad de la infección por $S$. enteritidis $(11,12)$.

Con las limitaciones mencionadas, la consistencia con estudios previos (5), la analogía con las alteraciones hepáticas en infecciones con otras especies de Salmonella $(2,3)$ y la plausibilidad biológica ya mencionada también, apoyan que la infección por $S$. enteritidis es la causa de las alteraciones encontradas en los enzimas hepáticos. El estudio longitudinal (cohorte retrospectiva), aunque realizado en un número limitado de casos con elevación de los enzimas hepáticos, demostró una tendencia significativa a la normalización en la fase de convalecencia, sugiriendo también que la infección por $S$. enteritidis es causa de tal elevación. Esta elevación de los enzimas hepáticos, si bien en general leve y autolimitada, es frecuente y se debe tener en cuenta en los pacientes con enterocolitis grave por $S$. enteritidis. 